\title{
Compression and Three-Point Bending Analyzes of Aerospace Sandwich Composites Produced with Polymeric Core Materials using ANSYS
}

\author{
Erdem Tunca ${ }^{1 *}$, Haşim Kafalı ${ }^{2}$ \\ 1* Muğla Sitkı Koçman University, Dalaman School of Civil Aviation, Muğla, Turkey, (ORCID: 0000-0003-3488-8282), erdemtunca@mu.edu.tr \\ ${ }^{2}$ Muğla Sitkı Koçman University, Dalaman School of Civil Aviation, Muğla, Turkey, (ORCID: 0000-0002-7740-202X), hasimkafali@mu.edu.tr
}

(First received 20 October 2021 and in final form 6 December 2021)

(DOI: 10.31590/ejosat.1012658)

ATIF/REFERENCE: Tunca, E. \& Kafal1, H. (2021). Compression and Three-Point Bending Analyzes of Aerospace Sandwich Composites Produced with Polymeric Core Materials with ANSYS. European Journal of Science and Technology, (31), 553-561.

\begin{abstract}
Honeycomb materials are widely used in aircraft structures. However, these structures have disadvantages in longitudinal compression forces. While aluminum is generally used as the face material in sandwich composites used in aircraft structures, Nomex honeycomb or aluminum honeycomb structures are used as the core material, depending on the design. The reduced interface area between the core and the surface layer also increases the probability of separation of the surface and core under an applied load. In this study, attention is drawn to the combination of polymeric foam - honeycomb structure as a potential material to eliminate or minimize these disadvantages of honeycomb core structures. In this study, polyurethane foam filled PLA (polylactic acid) honeycomb core sandwich composite with carbon fiber faces was subjected to compression and three-point bending tests in ANSYS. The results obtained show that this new material can be used in aerospace materials.
\end{abstract}

Keywords: Aeronautics, Honeycomb, Polyurethane, Sandwich Composite, ANSYS.

\section{Polimerik Çekirdek Malzemeler ile Üretilen Havacılık Sandviç Kompozitlerinin ANSYS ile Basma ve Üç Nokta Ĕğme Analizleri}

$\ddot{O} \mathbf{z}$

Bal peteği yapılar hava aracı malzemelerinde oldukça yaygın kullanım alanı bulmaktadır. Ancak bu yapılar boylamasına basma kuvvetlerinde dezavantajlara sahiptirler. Hava aracı yapılarında kullanılan sandviç kompozitlerde genellikle yüzey malzemesi olarak alüminyum kullanılırken çekirdek malzemesi olarak tasarıma göre değişmekle birlikte Nomex petek ya da alüminyum petek yapılar kullanılmaktadır. Çekirdek ve yüzey tabakası arasındaki azaltılmış arayüz alanı, uygulanan bir yük altında iken yüzey ile çekirdeğin ayrılma olasılığını da arttırmaktadır. Bu çalışmada bal peteği çekirdekli yapıların bu dezavantajlarını ortadan kaldırmak veya en aza indirgemek için potansiyel bir malzeme olarak polimerik köpük - bal peteği yapı kombinasyonuna dikkat çekilmektedir. Bu çalışmada karbon fiber yüzeylere sahip içi poliüretan köpük dolgulu PLA (polylactic acid) bal peteği çekirdekli sandviç kompozit ANSYS'te basma ve üç nokta eğme testlerine tabii tutulmuştur. Elde edilen sonuçlar bu yeni malzemenin havacılık yapılarında kullanılabileceğini göstermektedir.

Anahtar Kelimeler: Havacılık, Bal Peteği, Poliüretan, Sandviç Kompozit, ANSYS.

*Corresponding Author: erdemtunca@mu.edu.tr 


\section{Introduction}

Composite materials find an increasing use in industries thanks to their high performance / mass ratio. Due to its lightweight, it finds an increasing area of use especially in the aviation industry. This high performance to mass ratio is caused by the use of materials with certain mechanical properties such as carbon, glass or Kevlar. In Figure 1, the material types and usage areas of the Boeing 787 aircraft are given. As can be seen from this graph, composite materials are finding an increasing area of use in the aviation industry and it is seen that composite materials are used more than other materials in the aviation industry (Bouvet, 2017).

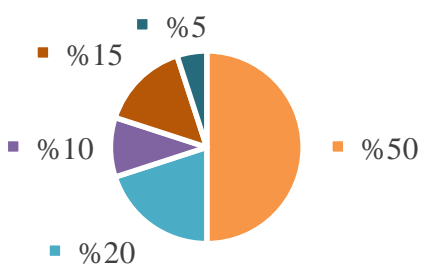

- Composite - Aluminum - Steel - Titanium - Others

Figure 1. Materials usage rates of Boeing 787 aircraft (Bouvet, 2017)

Hermann et al. (2005) stated that while designing an aircraft, it is essential to choose materials that will lighten the structure as much as possible without reducing the strength. However, lightweight materials must be able to withstand loads that are the dual combination of these loads, in addition to the tensile and compressive loads on the structure. This requires the reinforcement of thin surfaces. T. von Karman and P. Stock received a first patent for a glider plane using sandwich construction for the fuselage structure. This situation can be considered as the first use of sandwich structures in aviation. The development and application of sandwich structures is progressing and has great potential in commercial aviation in the near and medium term. As shown in Figure 2 there is a wide variety of sandwich composite applications in AIRBUS aircraft. These applications are; typically seen on exterior structures, aerodynamic trims, hatches and doors. Also, throughout the AIRBUS fleet, there are various control surfaces made of sandwich composites (e.g. flight control surfaces such as rudder, aileron, spoiler). Since aircraft are exposed to very different environmental conditions, sandwich structures need different requirements.

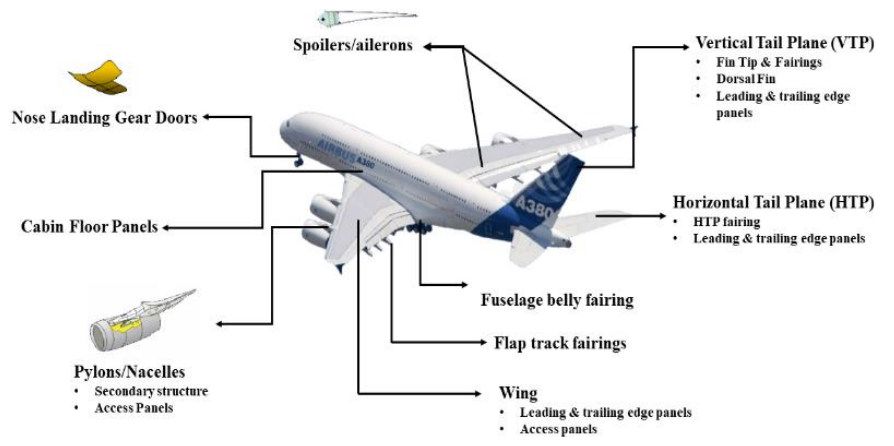

Figure 2. Sandwich composite applications on Airbus A380 aircraft (Hermann et al., 2005)
During the flight, the external structures of the aircraft are exposed to different operating temperatures and aerodynamic loads arising from the flight. Radomes and leading-edge coatings are subject to impacts from bird strikes and abrasion from hail, lightning strikes, rain and dust. Also, electromagnetic wave transmittance is required for radar and avionic devices. Foreign body damage (FOD) caused by runway contamination poses a threat to surfaces in the lower part of the aircraft. These situations reveal various requirements (operational and environmental requirements) for sandwich composite structures to be used in different regions. Various combinations of sandwich composites can be found to meet such different needs in aircraft structures. Figure 3 shows the components that make up the sandwich composite. Common surface materials for sandwich composites are carbon fiber reinforced prepregs with glass fiber and epoxy resin matrix. The dominant core material for sandwich composites is NOMEX ${ }^{\circledR}$ honeycomb (Hermann et al., 2005). Toozandehjani et al. (2018) stated that the most widely used types of structural composites in the aerospace industry are layered composites and sandwich composite structures. Since sandwich composites are in the structural composite class, they are used in beams and panels that require high rigidity and strength. The outer layers of the sandwich composite are manufactured from a relatively hard and durable material (i.e. aluminum alloys, fiber-reinforced plastics, titanium, steel or plywood). Since the outer layers meet the load on the sandwich composite, they must be strong enough to meet the tensile and compression loads caused by the load. Therefore, the outer layers must be sufficiently rigid and thick. The core material should be light and have a low modulus of elasticity.

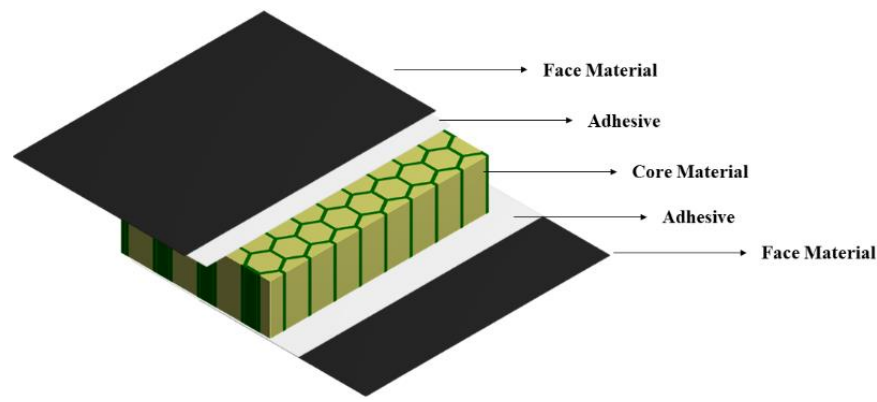

Figure 3. Components that make up the sandwich composite

Core materials typically categorized three subcategories. (1) Rigid polymeric foams (ie phenolics, epoxy, polyurethanes), (2) wood (i.e. balsa wood), and (3) honeycomb structures. Structurally, the core serves a variety of functions. The most basic function of the core material is to support the face materials. The core material must have sufficient shear strength and in addition be thick enough to provide high shear stiffness. Since the outer layers meet the main load on the structure, the tensile and compression loads on the core material are less than faces (Callister and Rethwisch, 2010). Xiong et al. (2019) stated that the core materials in sandwich composites should be both light and able to withstand the loads on them. Common configurations of lightweight cores include corrugated cores, honeycombs, foldcores, foam cores, and lattice cores. The manufacturing and maintenance challenges of traditional honeycomb core material with a higher surface area can be overcome by using polymeric foam cores. While the lower and upper layers of sandwich composite structures have a high strength but a thin structure, the core part has a lower strength compared to the layers and a high ability to absorb energy. Sandwich structures with honeycomb cores are preferred in order to absorb energy, especially in regions where high mechanical behaviour is expected under impact loads. 
Honeycomb core sandwich composites are structures that show high strength under impact and compression loads. In order to structures with honeycomb core geometry to be preferred in applications, their mechanical properties should be known. In order to detect these properties, their properties can be determined in various ways such as impact test, bending test and compression test. It is known that composite materials with honeycomb core have high strength depending on the applied load in the surface impact tests and compression tests (Liu et al., 2019). Considering the sandwich composite structure with honeycomb core, delamination can easily occur in the structure since the honeycomb structure can only be adhered from the cell wall region seen in Figure 4. In order to improve the honeycomb structure, the following four items should be selected effectively (Zhang et al., 2015);

- Cell wall material

- Cell wall thickness

- Cell size

- Cell porosity.

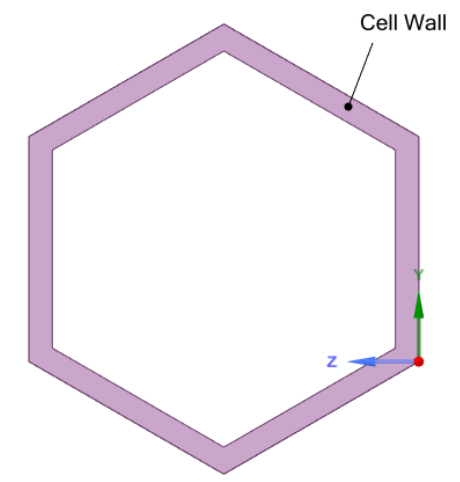

\section{Figure 4. Representation of cell wall in honeycomb structure}

However, due to the small amount of confining space between the honeycomb core materials and the surface layers, the honeycombs have strength limitations. The only way to increase the confining surface area is to increase the cell wall thickness. In addition, with the increase of the cell wall thickness, the weight of the structure may increase, which is an undesirable situation that contradicts the purpose of maintaining high strength and low weight of composite materials (Zhang et al., 2015). In addition, since the honeycomb structure is hollow, interfacial hardening methodologies are not suitable throughout the overall thickness. However, the foam-filled honeycomb core structure is suitable for this process. In addition, the foam-filled honeycomb core resists the load without premature bending or breaking under load. In contrast to hollow honeycomb cores, the foam core exhibits improved resistance to delamination and separation of interfacial bonds, due to an additional adhesive area of foam-filled honeycomb cells. Filling the honeycomb structure with foam improves the compression performance as well as the impact resistance of the sandwich structures. (Jayaram et al., 2019). Polymeric foam cores, due to the nature of the polymeric foam, destroy the moisture absorption capacity and layer separation of the surface layers. Thus, it can be ensured that these structures remain durable in humid environments and withstand loads and stresses. Polymeric foams provide low weight, ease of production, low production and maintenance costs, and most importantly, in addition to all these conveniences, they provide better mechanical strength (AZOM Materials, 2014). Sandwich composites used in aircraft structures generally use aluminum as the face material and Nomex honeycomb or aluminum honeycomb structures as the core material, depending on the design. Honeycomb is attractive both for its high compressive strength and light weight and has a hollow structure as shown in Figure 2. However, honeycombs have some disadvantages when used for structural components of aircraft. When a crack starts in the honeycomb core sandwich composite, this crack can easily lead to a potential ingress of water into the open cell structure. Given the temperature variation an aircraft undergoes during operation, the evaporation and freezing of this water within the voids can result in internal damage to the sandwich composite that reduces service time for the structure (Çağlayan et al., 2019). In addition, the reduced interface area between the core and the surface layer increases the probability of separation of the surface and core when under an applied load. To overcome these disadvantages of honeycomb core structures, attention is drawn to polymeric foams as a potential material to minimize moisture absorption and separation. Polymeric foams are gaining increasing attention in both the scientific and industrial communities due to the advantages of lightness, rigidity and also multifunctionality (Çağlayan et al., 2019; Lee et al., 2005).

Polyurethane foams are formed by the reaction of polyol and isocyanate components. The use of polyol and isocyanate components in different proportions during the production of the foam provides foams with different properties. The soft segment (polyol) retains the elastomeric properties, while the hard segment (isocyanate) controls the stiffness and toughness properties (Rahman et al., 2019). One of the important monomers of PU is the commercially available polyol and can also be synthesized in laboratories by different techniques. The most commonly used polyols are known as polyether polyol and polyester polyol It is common to use mixed polyols of different molecular weights and ratios to meet specific properties depending on the area in which the foam will be used. Different crosslinkers, additives and nanoparticles may also be included during PU synthesis. Depending on the application site, surfactants, blowing agents and pigments are also mixed into the PU (Rahman et al., 2019). Polymer foams have the advantage of adapting mechanical properties and adding versatility to their structure. In this way, it becomes attractive for various applications from insulation materials used in buildings to structural components of aircraft. Given these reinforcement pathways, sandwich composites using polymer foam as the core material can perform a variety of tasks, such as acoustic damping, a structural member against bending or impact, or a structure for electromagnetic interference (EMI) shielding (Caglayan et al., 2019).

In this study, hollow and foam-filled honeycomb core structures analyzes will be carried out, in which the disadvantages are eliminated by using these two materials together, as opposed to using only honeycomb core structure or using only polymeric foams in the literature. In this study, compression and three-point bending test' finite element analyses (FEA) were performed on ANSYS using a polyurethane foam filled PLA (polylactic acid) honeycomb core. The analysis results obtained were evaluated in terms of aerospace materials, and the potential for use in aerospace of this core structure, which consists entirely of polymeric materials, was interpreted. 


\section{Material and Method}

As mentioned before, polyurethane foams are formed by the reaction of polyol and isocyanate components. The properties of polyurethane foam in the 'Granta Design Sample Materials' library in the ANSYS $2020 \mathrm{R} 1$ program are given in Table 1. The properties of PLA (polylactic acid) in the 'Granta Design Sample Materials' library in the ANSYS 2020 R1 program are given in Table 2.

Table 1. Properties of polyurethane foam in ANSYS 2020 R1

\begin{tabular}{ll}
\hline Properties & Value and Unit \\
\hline Density & $192 \mathrm{~kg} / \mathrm{m}^{3}$ \\
Young's Modulus & $6,61 \mathrm{E}+07 \mathrm{~Pa}$ \\
Poisson's Ratio & 0,316 \\
Bulk Modulus & $5,9873 \mathrm{E}+07 \mathrm{~Pa}$ \\
Shear Modulus & $2,5114 \mathrm{E}+07 \mathrm{~Pa}$ \\
Tensile Yield Strength & $1,09 \mathrm{E}+06 \mathrm{~Pa}$ \\
Tensile Ultimate Strength & $2,19 \mathrm{E}+06 \mathrm{~Pa}$ \\
\hline
\end{tabular}

Table 2. Properties of PLA (polylactic acid) in ANSYS 2020 RI

\begin{tabular}{ll}
\hline Properties & Value and Unit \\
\hline Density & $1250 \mathrm{~kg} / \mathrm{m}^{3}$ \\
Young's Modulus & $3,45 E+09 \mathrm{~Pa}$ \\
Poisson's Ratio & 0,39 \\
Bulk Modulus & $5,2273 \mathrm{E}+09 \mathrm{~Pa}$ \\
Shear Modulus & $1,241 \mathrm{E}+09 \mathrm{~Pa}$ \\
Tensile Yield Strength & $5,41 \mathrm{E}+07 \mathrm{~Pa}$ \\
Tensile Ultimate Strength & $5,92 \mathrm{E}+07 \mathrm{~Pa}$ \\
\hline
\end{tabular}

Geometric features of the honeycomb core structure drawn in CATIA V5 for finite element analysis are given in Figure 5 and 6. Figure 5 shows the geometric properties of the edge length and cell wall thickness of a hexagonal structure (of a cell). Accordingly, while one side of the hexagonal structure is $13 \mathrm{~mm}$, the cell wall thickness is designed as $3 \mathrm{~mm}$.

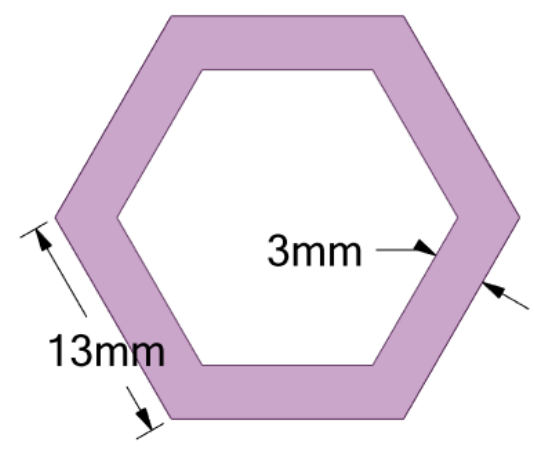

Figure 5. Dimensions of the hexagonal structure

As shown in Figure 6, the dimensions of the honeycomb core used in the analyzes were determined as $220 \times 150 \times 50 \mathrm{~mm}$. Carbon fiber faces have been added to the bottom and top faces of the foam filled honeycomb core in the ANSYS ACP module. The same process was applied to the hollow honeycomb core in the ANSYS ACP module.
The produced sandwich composites are shown in Figure 7. The mass values obtained from ANSYS for the produced sandwich composites are given in Table 3 .

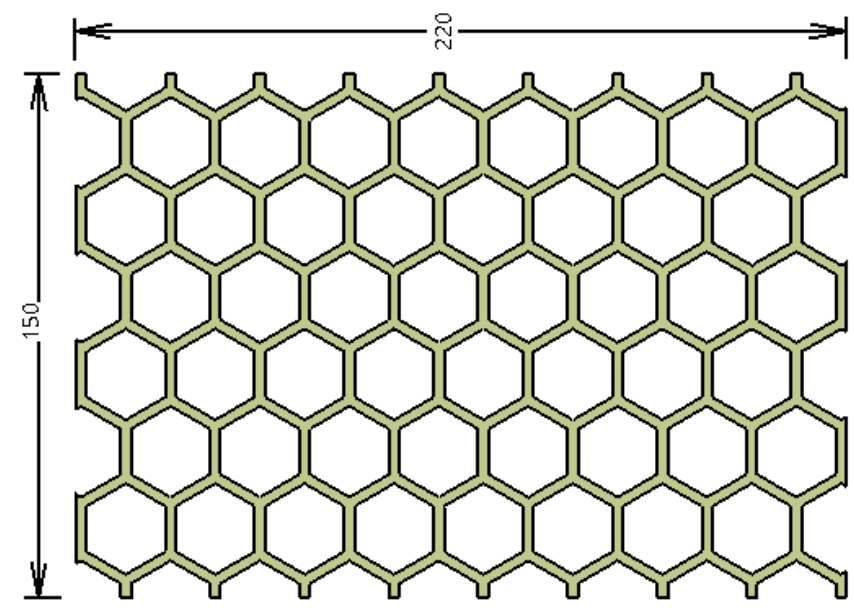

Figure 6. Dimensions of the honeycomb structure

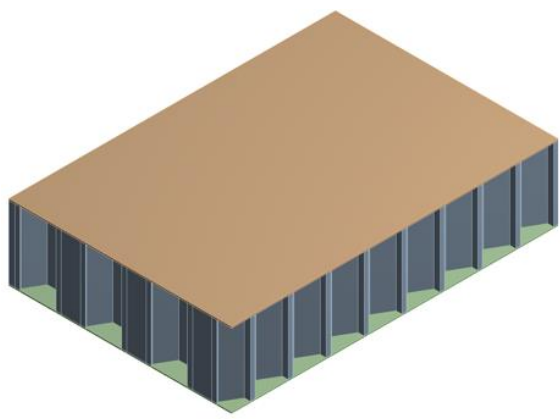

(a)

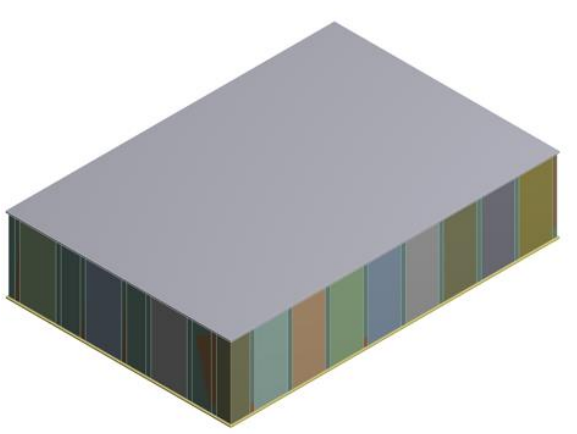

(b)

Figure 7. Sandwich composites produced in ANSYS (a) hollow honeycomb core, (b) foam filled honeycomb core

Table 3. Mass values of analysis materials

\begin{tabular}{ll}
\hline Material & Mass \\
\hline $\begin{array}{l}\text { Carbon fiber faces + PLA honeycomb } \\
\text { core }\end{array}$ & $0,98615 \mathrm{~kg}$ \\
$\begin{array}{l}\text { Carbon fiber faces + Polyurethane foam } \\
\text { filled honeycomb core }\end{array}$ & $1,5073 \mathrm{~kg}$ \\
\hline
\end{tabular}




\subsection{Analysis Settings}

Analyzes on ANSYS were performed separately for sandwich composite with hollow PLA honeycomb structure and for sandwich composite with polymeric foam filled PLA honeycomb core. As mentioned before, compression and threepoint bending tests were performed. Flatwise and edgewise compression tests were carried out for the compression test. In this section, the boundary conditions determined for the analysis are shown. Boundary conditions are only shown for the sandwich composite with a hollow honeycomb core. Analyzes were carried out using the same boundary conditions for the sandwich composite with a foam filled honeycomb core.

Figure 8 shows the surfaces on which the forces are applied during the compression tests and the fixed supports. Figure 9 shows the boundary conditions for the three-point bending test.

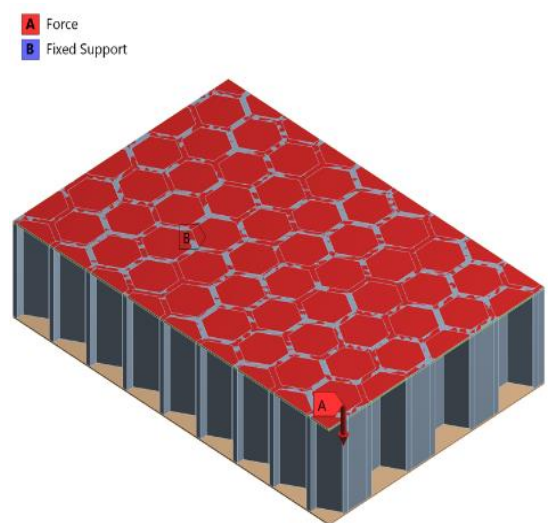

(a)

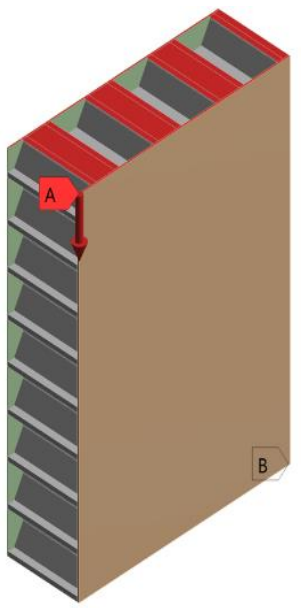

(b)
Figure 8. Surfaces where forces are applied in compression analysis and fixed supports (a) flatwise compression, (b) edgewise compression
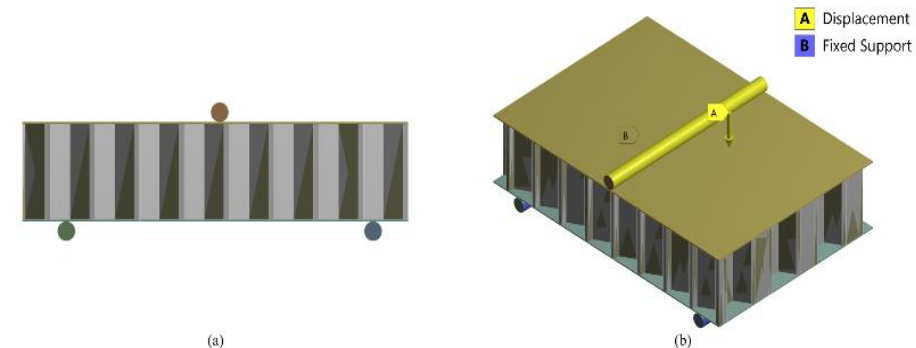

Figure 9. Three-point bending test set-up (a) bending surfaces (b) fixed support surfaces and displacement vector

The force values for compression tests are up to $125 \mathrm{kN}$. In the three-point bending test, the displacement value is up to 15 $\mathrm{mm}$.

\section{Results and Discussion}

\subsection{Flatwise Compression Test Results}

The total deformation values obtained after the flatwise compression test are shown in Figure 10. According to these values, a maximum total deformation of $0,77228 \mathrm{~mm}$ occurred in the hollow honeycomb structure, while a maximum total deformation of $0,6885 \mathrm{~mm}$ occurred in the polyurethane foam filled honeycomb structure. Figure 11 shows the equivalent (vonMises) stress values after the flat compression test. In the light of these values, a maximum equivalent stress value of 931,54 $\mathrm{MPa}$ was observed in the hollow honeycomb structure, while a maximum equivalent stress value of $675,98 \mathrm{MPa}$ was obtained in the foam-filled honeycomb structure. Figure 12 shows the equivalent elastic strain values after the flat compression test. In the scope of these values, a maximum elastic strain value of 0,031436 was observed in the hollow honeycomb structure, while a maximum elastic strain value of 0,09071 was obtained in the foam-filled honeycomb structure. Yan et al. filled the 3D printed honeycomb core with insulation foam (polymethacrylimide PMI) and examined their mechanical behaviour. Although the compressive strength of the foam filled honeycomb structure increased by $23.5 \%$ in flatwise compression test, there was not much change in the elastic modulus and energy absorption ability. The foam filling did not make a huge difference in flatwise compression, but it was quite effective in edgewise compression strength (Yan et al., 2020).

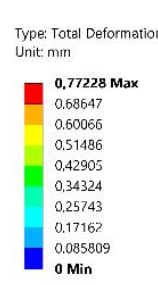

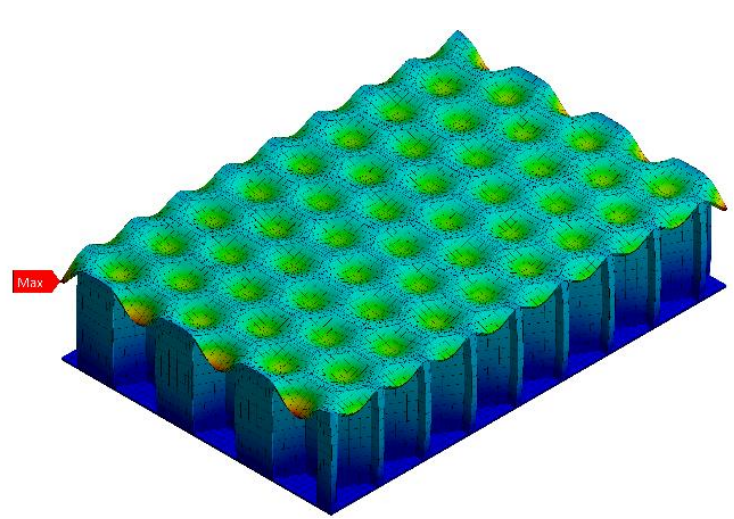

(a)
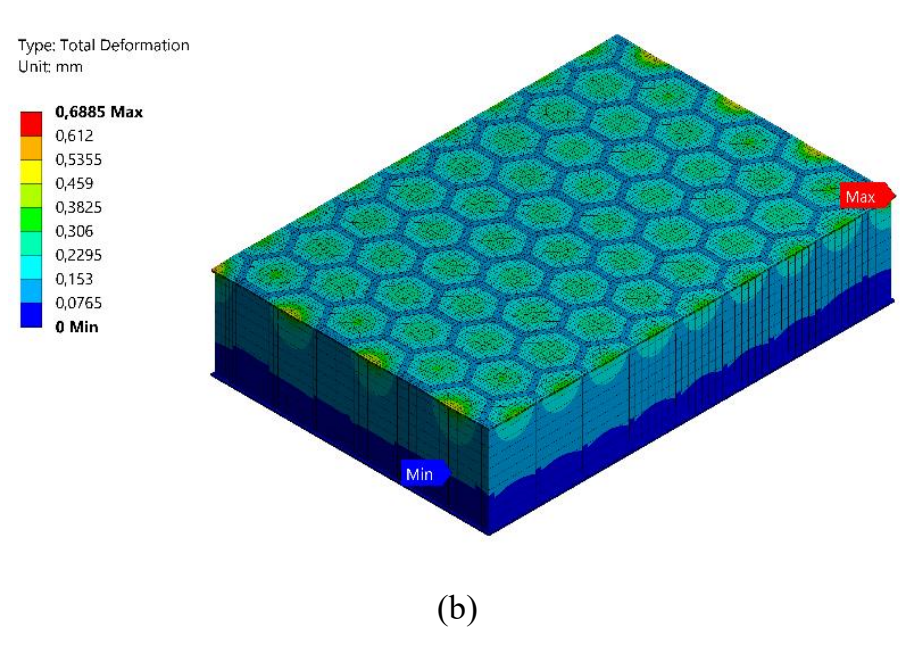

(b)

Figure 10. Flatwise compression test total deformation results (a) hollow honeycomb (b) foam filled honeycomb 


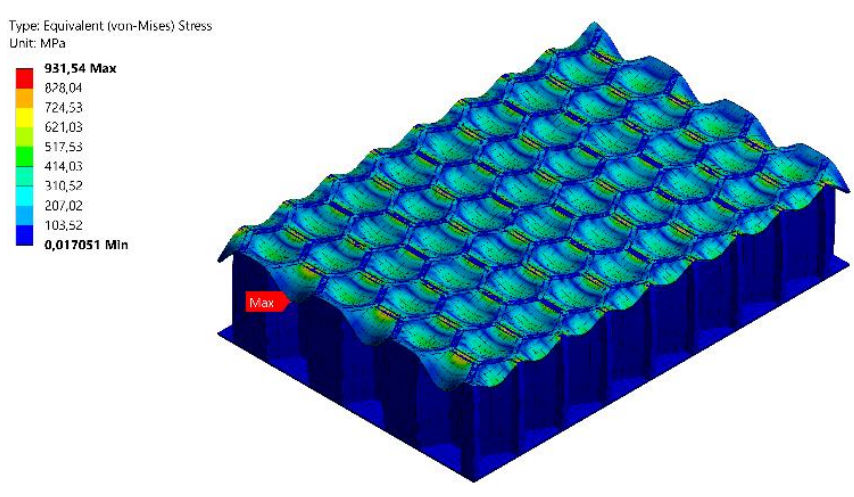

(a)

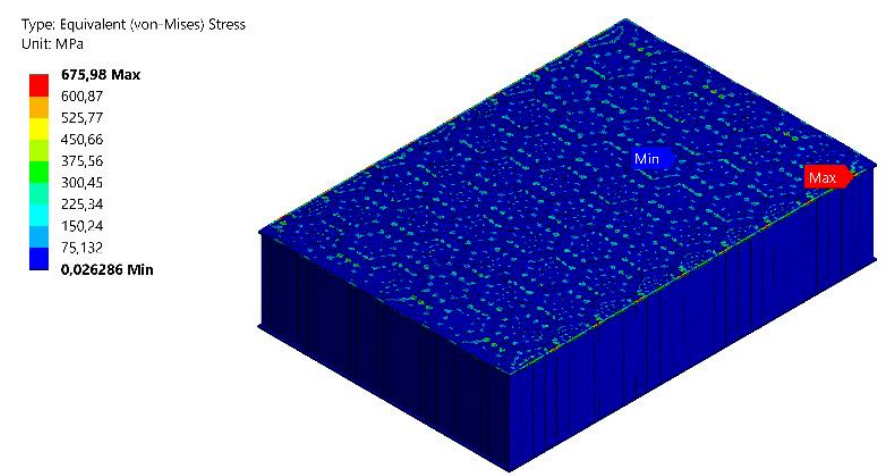

(b)

Figure 11. Flatwise compression test equivalent stress results (a) hollow honeycomb (b) foam filled honeycomb
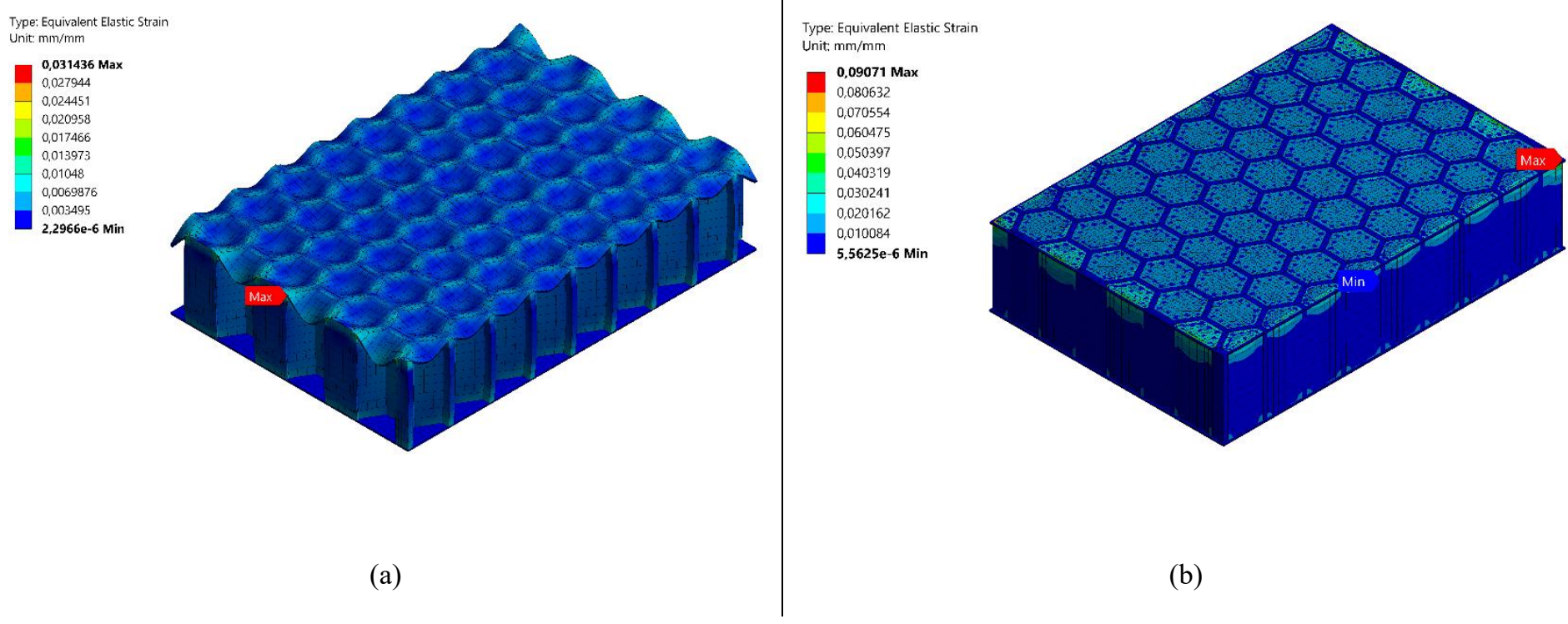

Figure 12. Flatwise compression test equivalent elastic strain results (a) hollow honeycomb (b) foam filled honeycomb

\subsection{Edgewise Compression Test Results}

The total deformation values obtained after the flatwise compression test are shown in Figure 13. According to these values, a maximum total deformation of $16,101 \mathrm{~mm}$ occurred in the hollow honeycomb structure, while a maximum deformation of $4,1001 \mathrm{~mm}$ occurred in the polyurethane foam filled honeycomb structure. Figure 14 shows the equivalent (vonMises) stress values after the flatwise compression test. In the light of these values, a maximum equivalent stress value of 8465,8 $\mathrm{MPa}$ was observed in the hollow honeycomb structure, while a maximum equivalent stress value of $1760,2 \mathrm{MPa}$ was obtained in the foam-filled honeycomb structure. Figure 15 shows the equivalent elastic strain values after the flatwise compression test. In the scope of these values, a maximum elastic strain value of 0,38855 was observed in the hollow honeycomb structure, while a maximum elastic strain value of 0,51463 was obtained in the foam-filled honeycomb structure. Yan et al. in the edgewise compression tests they applied to the $3 \mathrm{D}$ printed honeycomb structure filled with insulation foam, they observed quite good improvements in mechanical strength. According to the results they obtained, they observed an improvement of $306.5 \%$ in the longitudinal compression direction (L-direction) and $410.5 \%$ in the transverse (W-direction) compression direction (Yan et al., 2020). 


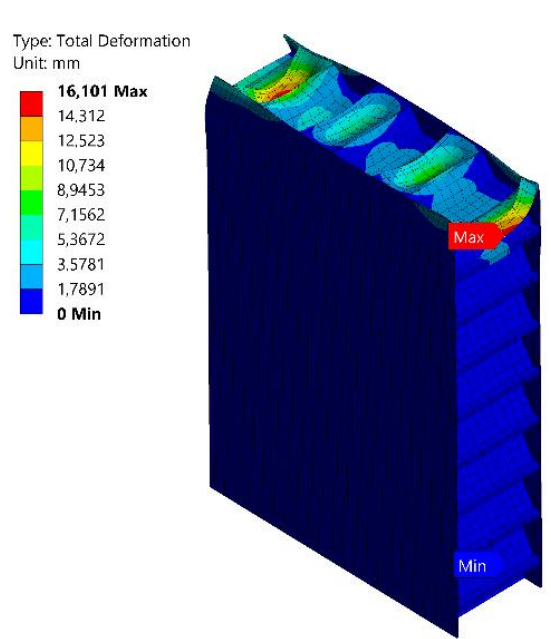

(a)

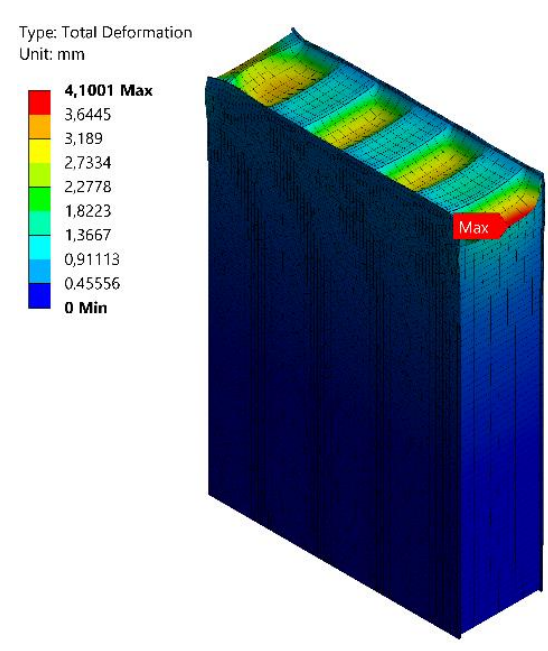

(b)

Figure 13. Edgewise compression test total deformation results (a) hollow honeycomb (b) foam filled honeycomb

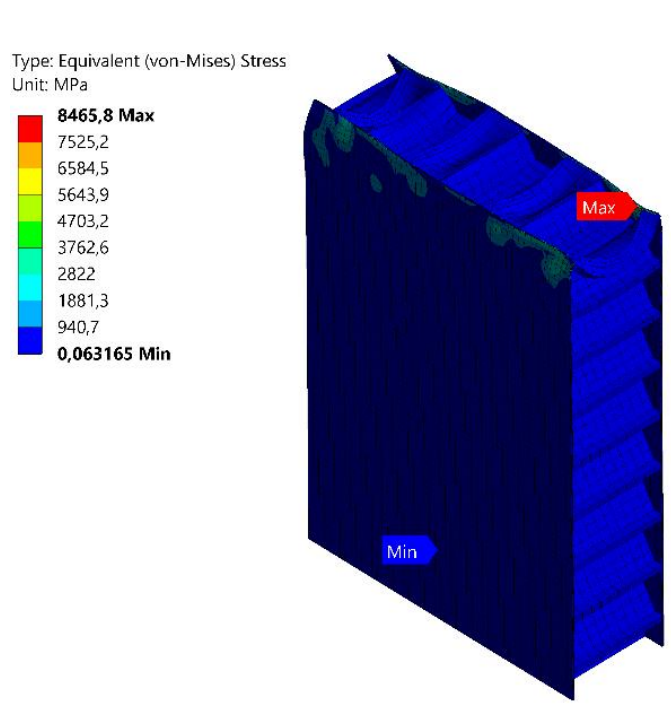

(a)

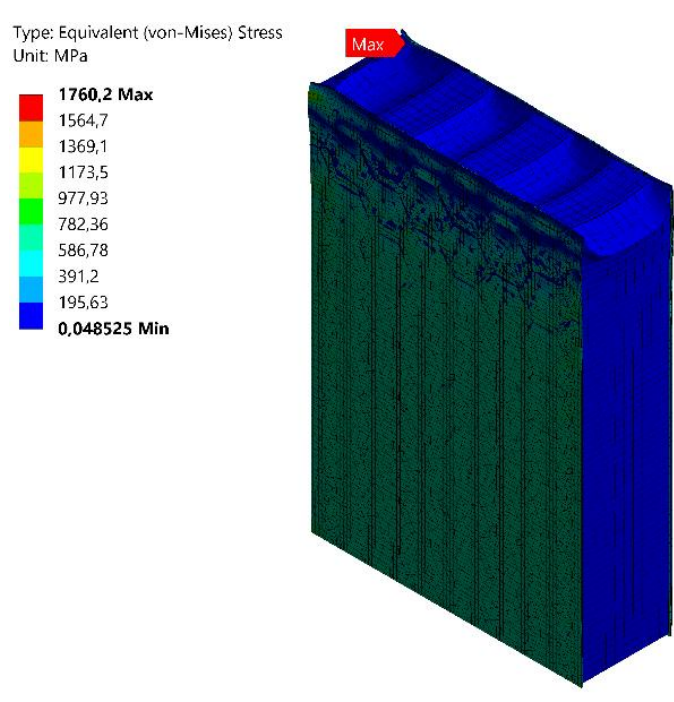

(b)

Figure 14. Edgewise compression test equivalent stress results (a) hollow honeycomb (b) foam filled honeycomb

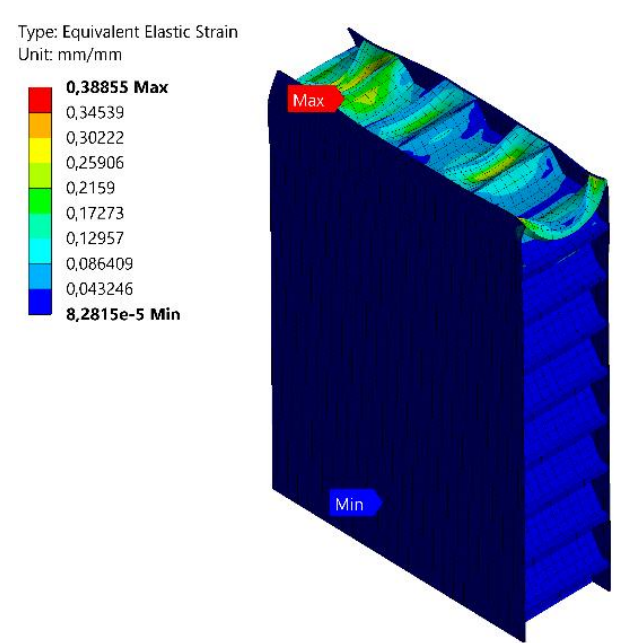

(a)

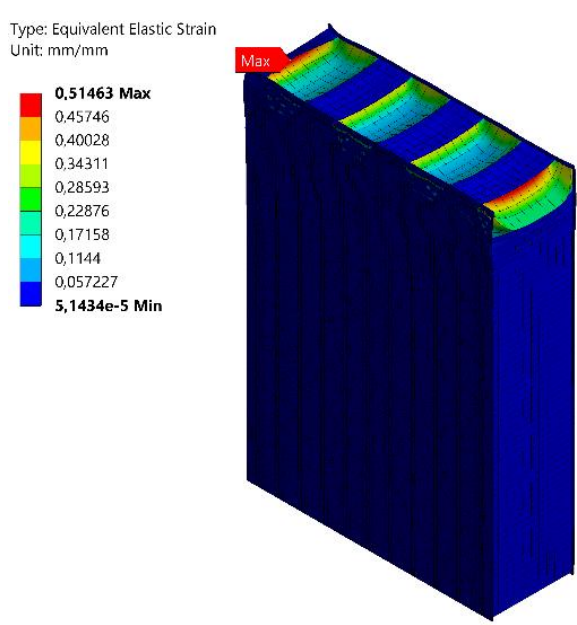

(b)

Figure 15. Edgewise compression test equivalent elastic strain results (a) hollow honeycomb (b) foam filled honeycomb 


\subsection{Three-Point Bending Test Results}

The total deformation values obtained after the three-point bending test are shown in Figure 16. According to these values, a maximum total deformation of $15,988 \mathrm{~mm}$ occurred in the hollow honeycomb structure, while a maximum total deformation of $15,245 \mathrm{~mm}$ occurred in the polyurethane foam filled honeycomb structure. Figure 17 shows the equivalent (von-Mises) stress values after the three-point bending test. In the light of these values, a maximum equivalent stress value of $8695,5 \mathrm{MPa}$ was observed in the hollow honeycomb structure, while a maximum equivalent stress value of $10460 \mathrm{MPa}$ was obtained in the foam- filled honeycomb structure. Figure 18 shows the equivalent elastic strain values after three-point bending test. In the scope of these values, a maximum elastic strain value of 0,47169 was observed in the hollow honeycomb structure, while a maximum elastic strain value of 0,11888 was obtained in the foam-filled honeycomb structure. In a study in the literature, bending tests were carried out using two different core materials (nomex core, 3D printed core) whose face materials are glass epoxy. According to the results, the $3 \mathrm{D}$ printed core showed more resistance to the load than the nomex core. The 3D printed core was able to withstand a peak load of $2266.60 \mathrm{~N}$ (Pirouzfar and Zeinedini, 2021).
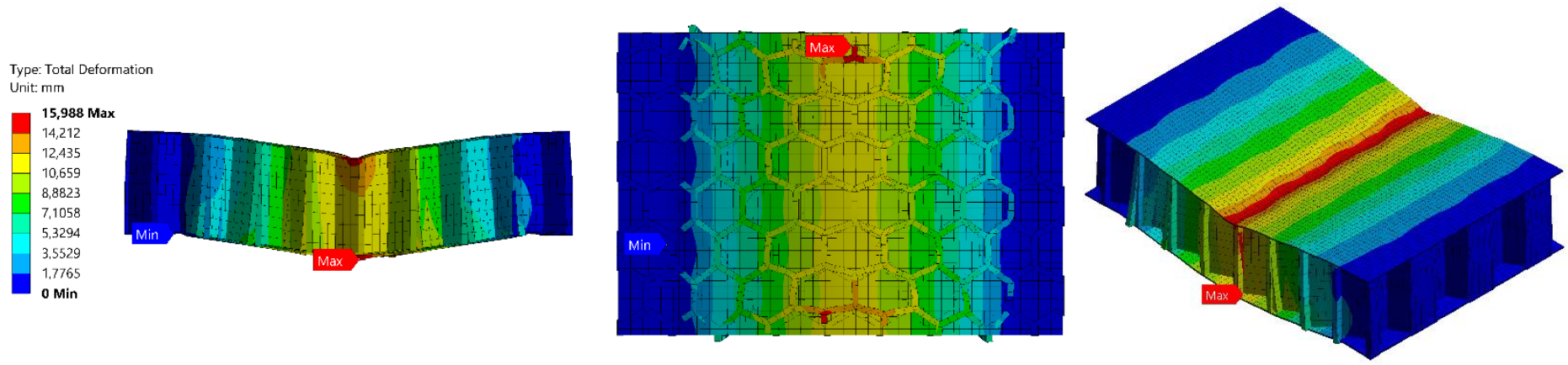

(a)
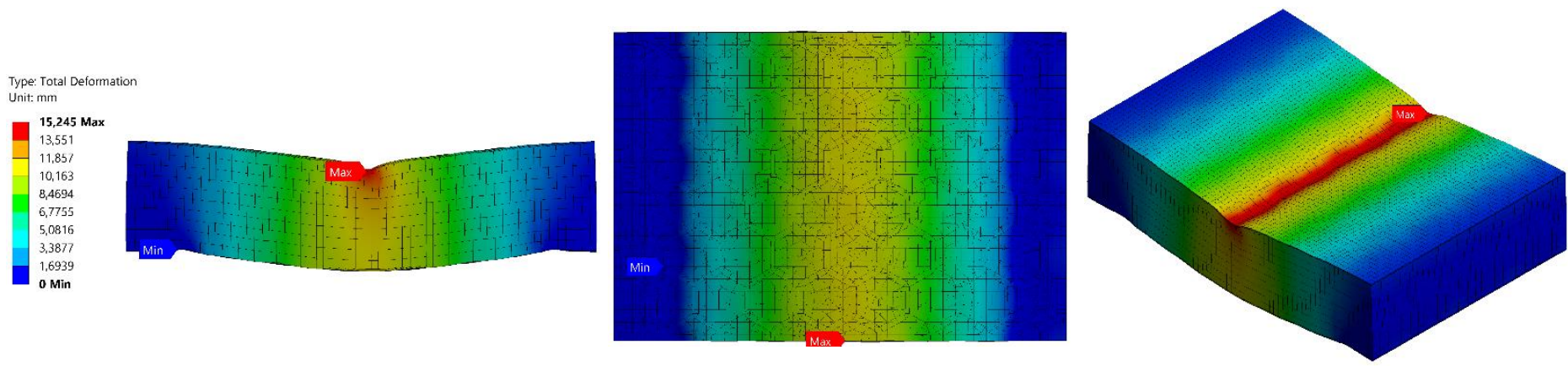

(b)

Figure 16.Three-point bending test total deformation results (a) hollow honeycomb (b) foam filled honeycomb

Type: Equivalent (von-Mises) Stress
Unit: MPa
$\begin{aligned} & \mathbf{8 6 9 5 , 5} \text { Max } \\ & 7729,4 \\ & 6763,2 \\ & 5797 \\ & 4830,9 \\ & 3864,7 \\ & 2898,5 \\ & 1932,3 \\ & 966,17 \\ & \mathbf{0} \text { Min }\end{aligned}$

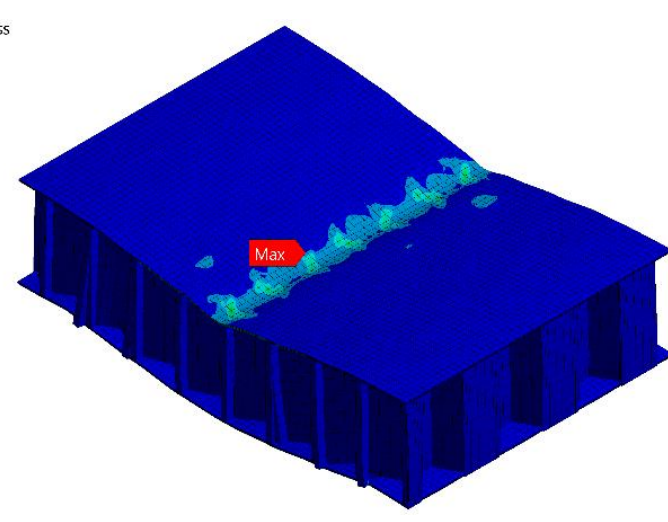

(a)
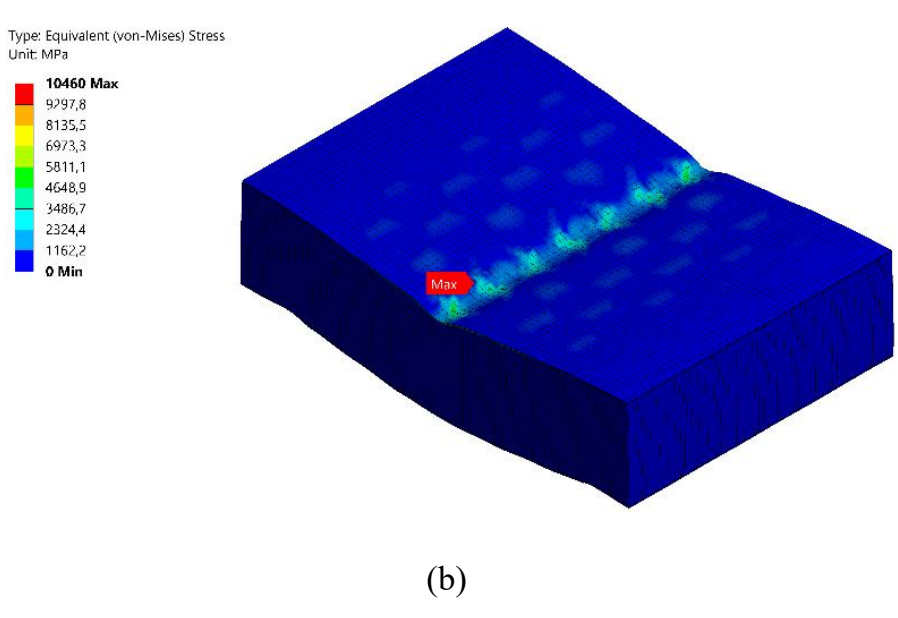

(b)

Figure 17. Three-point bending test equivalent stress results (a) hollow honeycomb (b) foam filled honeycomb 


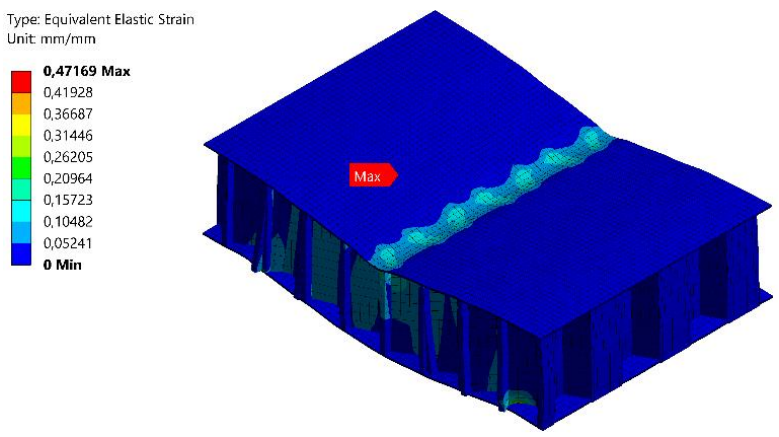

(a)

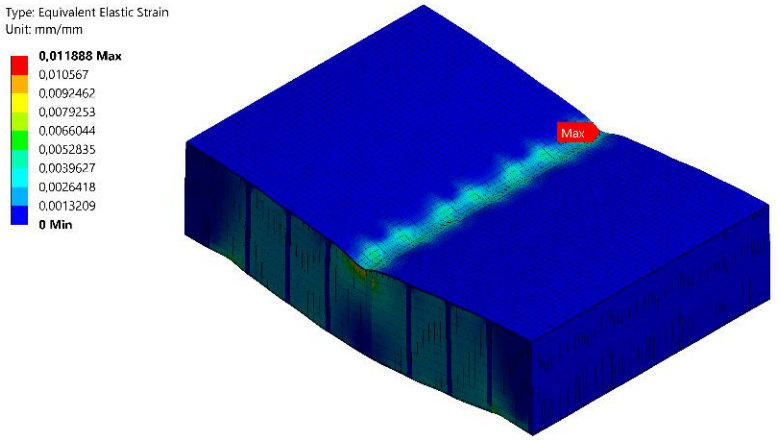

(b)

Figure 18. Three-point bending test equivalent elastic strain results (a) hollow honeycomb (b) foam filled honeycomb

\section{Conclusions and Recommendations}

When the results obtained within the scope of the analyzes are examined, the polyurethane foam filling significantly increased the mechanical strength. Although there was not a big difference in the total maximum deformation in the flatwise compression test, a 4 times visible difference was observed in the maximum total deformation in the edgewise compression test. This made the honeycomb structures of the foam filling more resistant to edgewise compression forces. Likewise, there is not much difference between the equivalent stress and equivalent strain values in the flatwise compression tests. However, significant differences were observed in the equivalent stress and equivalent strain values obtained in the edgewise compression test.

Since the foam filling is more effective in edgewise compression forces, when the results of the three-point bending test are examined, there is no significant difference in the total amount of deformation, but a significant difference is observed in the maximum equivalent stress and equivalent strain amounts. When the maximum equivalent stress values are examined, more stress has occurred in the polyurethane foam filled structure, unlike the compression test results. However, when the maximum equivalent strain amount is examined, it is seen that it is smaller despite the more stress that occurs. This is due to the effects of compressive force and tensile force occurring in the three-point bending test. Therefore, it is seen that the sandwich composite with polyurethane foam filled core is more successful in the threepoint bending test. Foam filling has only one disadvantage, which is the relative increase in weight. As can be seen in Table 3, an increase of approximately $52 \%$ occurred in weight. Open cell (flexible) polyurethane foams can be used to reduce the weight increase effect. The proposed material can be used in aircraft fuselage structures, cabin floor structures, wings and flight control surfaces. The proposed material can be used as wing construction material in aircraft (i.e. commercial aircraft, fighter aircraft, and unmanned aircraft), especially since the wing roots are subjected to intense compression load.

\section{References}

Bouvet, C. (2017). Mechanics of Aeronautical Composite Materials. John Wiley \& Sons

Caglayan, C., Gurkan, I., Gungor, S., \& Cebeci, H. (2018). The effect of CNT-reinforced polyurethane foam cores to flexural properties of sandwich composites. Composites Part A: Applied Science and Manufacturing, 115, 187-195.

Callister, W. D., \& Rethwisch, D. G. (2011). Materials science and engineering (2010). John Wiley \& Sons.

Evonik Industries. (2019, July 15). Polymethacrylimide Foam for Damage Tolerant Structures for Better Damage Visibility in Aerospace https://www.azom.com/article.aspx?ArticleID=10501

Herrmann, A. S., Zahlen, P. C., \& Zuardy, I. (2005). Sandwich structures technology in commercial aviation. In Sandwich structures 7: Advancing with sandwich structures and materials (pp. 13-26). Springer, Dordrecht.

Jayaram, R. S., Nagarajan, V. A., \& Vinod Kumar, K. P. (2019). Compression and low velocity impact response of sandwich panels with polyester pin-reinforced foam filled honeycomb core. Journal of Sandwich Structures \& Materials, 21(6), 2014-2030.

Lee, L. J., Zeng, C., Cao, X., Han, X., Shen, J., \& Xu, G. (2005). Polymer nanocomposite foams. Composites science and technology, 65(15-16), $2344-2363$.

Liu, J., Chen, W., Hao, H., \& Wang, Z. (2019). Numerical study of low-speed impact response of sandwich panel with tube filled honeycomb core. Composite Structures, 220, 736-748.

Pirouzfar, S., \& Zeinedini, A. (2021, October). Effect of geometrical parameters on the flexural properties of sandwich structures with 3D-printed honeycomb core and Eglass/epoxy Face-sheets. In Structures (Vol. 33, pp. 27242738). Elsevier.

Rahman M.M., Rabbani M.M., Saha J.K. (2019) Polyurethane and Its Derivatives. In: Jafar Mazumder M., Sheardown H., Al-Ahmed A. (eds) Functional Polymers. Polymers and Polymeric Composites: A Reference Series. Springer, Cham.

Toozandehjani, M., Kamarudin, N., Dashtizadeh, Z., Lim, E. Y., Gomes, A., \& Gomes, C. (2018). Conventional and advanced composites in aerospace industry: technologies revisited. Am. J. Aerosp. Eng, 5, 9-15.

Xiong, J., Du, Y., Mousanezhad, D., Eydani Asl, M., Norato, J., \& Vaziri, A. (2019). Sandwich Structures with Prismatic and Foam Cores: A Review. Advanced Engineering Materials, 21(1), 1800036.

Yan, L., Zhu, K., Zhang, Y., Zhang, C., \& Zheng, X. (2020). Effect of Absorbent Foam Filling on Mechanical Behaviors of 3DPrinted Honeycombs. Polymers, 12(9), 2059.

Zhang, Q., Yang, X., Li, P., Huang, G., Feng, S., Shen, C., ... \& $\mathrm{Lu}$, T. J. (2015). Bioinspired engineering of honeycomb structure-Using nature to inspire human innovation. Progress in Materials Science, 74, 332-400. 